\title{
Changes in Serum 25 Hydroxyvitamin D Concentrations in Male University Long-Distance Runners Following Vitamin D3 Supplementation During Winter: A Randomized Controlled Trial
}

Toraishi Mami ( $\sim$ mtoraishi0824@yahoo.co.jp)

Teikyo University: Teikyo Daigaku https://orcid.org/0000-0002-1514-4088

Kasai Mayumi

Teikyo University: Teikyo Daigaku

Nakano Takayuki

Teikyo University: Teikyo Daigaku

Sasahara Jun

Teikyo University: Teikyo Daigaku

Research article

Keywords: Long-distance runner, 25 hydroxyvitamin D, vitamin D3 supplement, winter

Posted Date: January 7th, 2021

DOI: https://doi.org/10.21203/rs.3.rs-138947/v1

License: @ (i) This work is licensed under a Creative Commons Attribution 4.0 International License. Read Full License 


\section{Abstract}

\section{Background}

Vitamin D insufficiency and deficiency remain a global problem, even among athletes. In this study, we evaluated the serum 25 hydroxyvitamin $\mathrm{D}[25(\mathrm{OH}) \mathrm{D}]$ concentrations of male long-distance runners during winter and the effect of short-term vitamin $D_{3}$ supplementation to elucidate their dietary vitamin $D$ requirements.

\section{Methods}

Using double-blind randomization, 34 athletes on the "Ekiden" (long-distance road race) team at University A were divided into a vitamin $D$ group $\left(n=17,25 \mu \mathrm{g}\right.$ /day of vitamin $D_{3}$ intake) and a placebo group $(n=17$, placebo tablet intake). Both groups ate normal meals with either the supplement or placebo included, and all subjects underwent a 31-day dietary survey. The pre- and post-intervention body composition and blood test were measured and compared.

\section{Results}

Prior to intervention, the vitamin $D$ intake amount was $16.7 \pm 7.2 \mu \mathrm{g} /$ day, but the serum $25(\mathrm{OH}) \mathrm{D}$ concentration was $28.9 \pm 5.7 \mathrm{ng} / \mathrm{mL}$, and $22(65 \%)$ of the 34 subjects had insufficient vitamin $\mathrm{D}(<30 \mathrm{ng} / \mathrm{mL})$. During the intervention period, the mean amount of vitamin $D$ intake was $40.0 \pm 5.5 \mu \mathrm{g} /$ day in the vitamin $D$ group and 13.4 $\pm 7.7 \mu \mathrm{g} /$ day in the placebo group. Serum $25(\mathrm{OH})$ D concentrations increased from $30.7 \pm 6.7 \mathrm{ng} / \mathrm{mL}$ to $35.4 \pm$ $6.6 \mathrm{ng} / \mathrm{mL}$ in the vitamin $\mathrm{D}$ group and from $27.1 \pm 3.9 \mathrm{ng} / \mathrm{mL}$ to $28.5 \pm 4.4 \mathrm{ng} / \mathrm{mL}$ in the placebo group, respectively $(p<0.001, p<0.01)$. After intervention, the serum $25(\mathrm{OH}) \mathrm{D}$ concentration in the vitamin $\mathrm{D}$ group was significantly higher $(p<0.001)$. Additionally, the rate of vitamin $D$ sufficiency was $82 \%$ in the vitamin $D$ group and $43 \%$ in the placebo group, indicating a significant difference $(p<0.01)$.

\section{Conclusions}

Our results demonstrate that post-intervention serum $25(\mathrm{OH})$ D concentration was related to both mean vitamin D intake amount during the intervention period and pre-intervention serum $25(\mathrm{OH}) \mathrm{D}$ concentration. However, to better quantify the required amount of vitamin $D$, further study of the effect of vitamin $D$ supplementation on bone health is needed.

\section{Background}

Vitamin $\mathrm{D}$ is involved in both bone and mineral metabolism. In addition to promoting the absorption of phosphorus and calcium, which are its main physiological actions, it is also involved in immune functions [1] and skeletal muscle functions [2]. Vitamin D is found in foods, such as fish and mushrooms, and is produced in the skin as a result of ultraviolet irradiation. After metabolic conversion in the liver to 25 hydroxyvitamin D [25 $(\mathrm{OH}) \mathrm{D}$, it binds to vitamin D binding protein (DBP) and then circulates via the bloodstream. Because of $25(\mathrm{OH})$ D's relatively long half-life of approximately 3 weeks, vitamin D nutritional status is used as an index to determine the amount of vitamin $\mathrm{D}$ that an individual obtains from their diet and skin [3]. It has been previously reported that low $25(\mathrm{OH})$ D levels are related to decreased intake of vitamin D and fish [4], and these decreased 
$25(\mathrm{OH})$ D levels increase the levels of serum parathyroid hormone (PTH), which promotes bone resorption, thereby increasing the risk of reduced bone density and fractures $[5,6]$.

In recent years, vitamin D insufficiency and deficiency have become a global problem [7], and it has been reported that these conditions also exist among athletes engaged in various sports [8-11]. Low 25 (OH) D concentrations, indicative of vitamin D insufficiency and deficiency, are frequently noted among indoor athletes who have little exposure to ultraviolet light during the winter months [10,11]. This is related to the risk of fatigue fracture [12-14], and vitamin D and calcium (Ca) intake are important to bone health and the prevention of stress fractures among athletes [15-17]. In recent years, studies have reported that vitamin D and Ca intake promote muscle protein synthesis [18], reduce the occurrence of upper respiratory tract infections [19], and improve aerobic capacity [20].

Dietary Reference Intake guides in the United States and Canada [21] established a serum 25 (OH) D concentration level that does not increase the risk of fracture and recommend a vitamin D intake of $15 \mu \mathrm{g} / \mathrm{day}$ for individuals aged $\leq 70$ years. Alternatively, the Dietary Reference Intake for Japanese (2020 edition) [22] has formulated an estimated amount of $8.5 \mu \mathrm{g}$ / day for individuals aged 18-29 years. However, this value is based on the median intake of healthy people; the amount required differs per individual and is influenced by individual vitamin D intake, latitude, season, outdoor activity amount, and the presence or absence of sunscreen use, which affects the amount of vitamin D produced by the skin.

Thus, the objective of the present study was to determine winter serum $25(\mathrm{OH}) \mathrm{D}$ concentrations in athletes and to investigate changes in the serum $25(\mathrm{OH}) \mathrm{D}$ concentration that occur as a result of vitamin $\mathrm{D}_{3}$ intervention to elucidate the amount of vitamin $\mathrm{D}$ required in male long-distance runners.

\section{Methods}

\section{Subjects and study period}

From an initial candidate pool of 43 male runners on the "Ekiden" (long-distance road race) team at University A, 34 athletes, who consented to participate in the study and for whom all relevant data was available, were included in this study. The subjects were athletes who engaged in training mainly in long-distance running outdoors six days per week. Using a random number table, double-blind randomization was performed, and the subjects were categorized into a group that ingested vitamin $D_{3}$ supplement tablets $(25 \mu \mathrm{g} /$ day: vitamin $D$ group) and a group that ingested placebo tablets (placebo group). Both groups ate normal meals with either the supplement or the placebo included. Those who did not participate in training owing to injury or physical deconditioning and those who were taking calcium and vitamin D supplements were excluded from the study. The intake rate of the test foods distributed to the subjects was confirmed using a daily survey, which showed that the intake rate during the survey period was $100 \%$.

The intervention period was a 31-day period between January 25 and February 23, 2019. This study was approved by the Institutional Review Board of Teikyo University (no. 18-155), and all subjects provided informed written consent.

\section{Measured items and measurement methods}


Bone mineral content (BMC) and bone mineral density (BMD) were measured using dual-energy X-ray absorptiometry (Horizon, TOYO MEDIC, Tokyo). Weight, body fat percentage, and minerals content were measured both prior to and following the intervention using 8-electrode multi-frequency impedance (InBody770, InBody Japan, Tokyo). Body mass index (BMI) was calculated based on body height and weight. Body height, $\mathrm{BMC}$, and $\mathrm{BMD}$ were measured prior to intervention only.

Pre- and post-intervention fasting blood tests were obtained to measure serum $25(\mathrm{OH}) \mathrm{D}$ concentration (CLEIA method), serum intact PTH (ECLIA method), serum calcium concentration (Ca, Arsenazo III method), serum inorganic phosphorus concentration (P, direct Molybdate method), and serum interleukin-6 (IL-6, CLEIA method). Blood tests were performed under contract by SRL Tokyo Medical (Tokyo). Serum 25 (OH) D levels of $\geq 30$ $\mathrm{ng} / \mathrm{mL}$ were considered to indicate sufficient vitamin D nutritional status [23], whereas those $<30 \mathrm{ng} / \mathrm{mL}$ indicated insufficient vitamin D.

During the 31-day intervention period of this study, food and drink intake were monitored using a diet record and photographs of the foods and drinks consumed. Excel Eiyo-kun software (Ver.8.0, Kenpakusha, Tokyo) was used to calculate the caloric intake as well as the mean protein, fat, carbohydrate, vitamin $D$, and calcium intake amounts.

\section{Statistical analysis}

All measured values are shown as the mean \pm standard deviation. The Shapiro-Wilk test was used to test the normality of all the variables. Pre- and post-intervention comparisons were performed using the paired $t$-test. Comparisons of the vitamin D and placebo groups were performed under the assumption of post-F-test homogeneity of variance and using the student's $t$-test. Comparisons of the vitamin D nutritional status between groups were performed using the chi-squared test. Simple regression analysis with post-intervention serum 25 $(\mathrm{OH}) \mathrm{D}$ concentration as the dependent variable and all factors as the independent variables was performed to analyze the relationship between post-intervention serum $25(\mathrm{OH}) \mathrm{D}$ concentration and the amounts of both energy intake and nutrient intake during the intervention period. Investigation of the factors that contribute to post-intervention serum $25(\mathrm{OH})$ D concentration was performed using multiple regression analysis (stepwise) with post-intervention serum $25(\mathrm{OH})$ D concentration as the dependent variable and pre-intervention serum 25 $(\mathrm{OH}) \mathrm{D}$ concentration, vitamin D intake amount, and calcium intake amount as the independent variables. Analysis of variance (ANOVA) was used to test whether the multiple regression was significantly established.

The relationship between the rate of change in the pre- and post-intervention serum $25(\mathrm{OH}) \mathrm{D}$ concentrations and all other factors was analyzed using Pearson's product moment correlation coefficient. All statistical analyses were performed using SPSS Statistic ver.23.0 (IBM, New York, US). All tests were two-sided tests, and the standard of statistical significance was set at $5 \%$.

\section{Results}

\section{Pre-intervention subject characteristics}

The subjects' mean age was $19.8 \pm 0.9$ years, the whole body BMC was $2303 \pm 211 \mathrm{~g}$, the whole body bone density was $1.126 \pm 0.058 \mathrm{~g} / \mathrm{cm}^{2}$, and the young adult mean (YAM) of the whole body bone density was $96.6 \pm$ $5.5 \%$. The pre-intervention vitamin D intake amount was $16.7 \pm 7.2 \mu \mathrm{g} / \mathrm{day}$, and 31 subjects (91\%) had intake 
amounts that exceeded the target amount. The serum $25(\mathrm{OH}) \mathrm{D}$ concentration was $28.9 \pm 5.7 \mathrm{ng} / \mathrm{mL}$, with 12 subjects (35\%) showing sufficient vitamin $D(\geq 30 \mathrm{ng} / \mathrm{mL})$ and $22(65 \%)$ showing insufficient vitamin $D(<$ $30 \mathrm{ng} / \mathrm{mL}$ ). There were no significant differences between the vitamin $D$ group and the placebo group regarding age, body height, weight, body fat percentage, BMC, BMD, YAM value, blood indices, energy, or nutritional intake amounts (Table 1). 
Table 1

Pre-intervention subject characteristics

\begin{tabular}{|c|c|c|c|c|c|c|c|c|c|c|c|}
\hline \multirow[b]{2}{*}{ Age } & \multirow[b]{2}{*}{ (yrs) } & \multicolumn{3}{|c|}{ All $(n=34)$} & \multicolumn{3}{|c|}{$\begin{array}{l}\text { Vitamin D group } \\
(n=17)\end{array}$} & \multicolumn{3}{|c|}{$\begin{array}{l}\text { Placebo group }(n= \\
17)\end{array}$} & \multirow{2}{*}{$\begin{array}{l}P \\
\text { value } \\
\text { n.s. }\end{array}$} \\
\hline & & 19.8 & \pm & 0.9 & 20.0 & \pm & 0.8 & 19.5 & \pm & 0.9 & \\
\hline Body height & $(\mathrm{cm})$ & 171.0 & \pm & 5.0 & 171.0 & \pm & 5.0 & 170.9 & \pm & 5.1 & n.s. \\
\hline Weight & $(\mathrm{kg})$ & 55.7 & \pm & 4.8 & 54.5 & \pm & 5.4 & 56.8 & \pm & 4.0 & n.s. \\
\hline $\begin{array}{l}\text { Body fat } \\
\text { percentage }\end{array}$ & $(\%)$ & 11.5 & \pm & 2.1 & 11.2 & \pm & 1.5 & 11.9 & \pm & 2.6 & n.s. \\
\hline $\begin{array}{l}\text { Minerals } \\
\text { contents }\end{array}$ & (g) & 2,888 & \pm & 298 & 2,840 & \pm & 347 & 2,935 & \pm & 240 & n.s. \\
\hline $\begin{array}{l}\text { Whole body } \\
\text { bone mineral } \\
\text { content }\end{array}$ & (g) & 2,303 & \pm & 211 & 2,257 & \pm & 235 & 2,348 & \pm & 179 & n.s. \\
\hline $\begin{array}{l}\text { Whole body } \\
\text { bone density }\end{array}$ & $\left(\mathrm{g} / \mathrm{cm}^{2}\right)$ & 1.126 & \pm & 0.058 & 1.122 & \pm & 0.067 & 1.130 & \pm & 0.050 & n.s. \\
\hline YAM & $(\%)$ & 96.6 & \pm & 5.6 & 96.8 & \pm & 6.0 & 96.4 & \pm & 5.4 & n.s. \\
\hline $\begin{array}{l}\text { Serum } \\
25(\mathrm{OH}) \mathrm{D} \\
\text { concentration }\end{array}$ & $(\mathrm{ng} / \mathrm{mL})$ & 28.9 & \pm & 5.7 & 30.7 & \pm & 6.7 & 27.1 & \pm & 3.9 & n.s. \\
\hline $\begin{array}{l}\text { Serum intact } \\
\text { PTH } \\
\text { concentration }\end{array}$ & $(\mathrm{pg} / \mathrm{mL})$ & 26 & \pm & 15 & 24 & \pm & 8 & 28 & \pm & 6 & n.s. \\
\hline $\begin{array}{l}\text { Serum } \\
\text { calcium } \\
\text { concentration }\end{array}$ & $(\mathrm{mg} / \mathrm{dL})$ & 9.6 & \pm & 0.3 & 9.8 & \pm & 0.3 & 9.6 & \pm & 0.2 & n.s. \\
\hline $\begin{array}{l}\text { Serum } \\
\text { inorganic } \\
\text { Phosphorus } \\
\text { concentration }\end{array}$ & $(\mathrm{mg} / \mathrm{dL})$ & 3.6 & \pm & 0.3 & 3.6 & \pm & 0.3 & 3.6 & \pm & 0.3 & n.s. \\
\hline $\begin{array}{l}\text { Serum } \\
\text { interleukin-6 } \\
\text { concentration }\end{array}$ & $(\mathrm{pg} / \mathrm{mL})$ & 0.76 & \pm & 0.68 & 0.68 & \pm & 0.29 & 0.83 & \pm & 0.93 & n.s. \\
\hline Energy intake & (kcal/day) & 3,075 & \pm & 479 & 3,152 & \pm & 569.0 & 3,012 & \pm & 396 & n.s. \\
\hline Protein intake & (g/day) & 119.5 & \pm & 25.6 & 124.2 & \pm & 29.4 & 115.6 & \pm & 22.1 & n.s. \\
\hline Fat intake & (g/day) & 83.0 & \pm & 23.8 & 85.7 & \pm & 26.3 & 80.8 & \pm & 22.0 & n.s. \\
\hline $\begin{array}{l}\text { Carbohydrate } \\
\text { intake }\end{array}$ & (g/day) & 449.4 & \pm & 79.0 & 458.1 & \pm & 88.7 & 442.3 & \pm & 71.6 & n.s. \\
\hline $\begin{array}{l}\text { Vitamin D } \\
\text { intake }\end{array}$ & ( $\mu \mathrm{g} /$ day) & 16.7 & \pm & 7.2 & 18.6 & \pm & 8.6 & 15.1 & \pm & 5.6 & n.s. \\
\hline
\end{tabular}




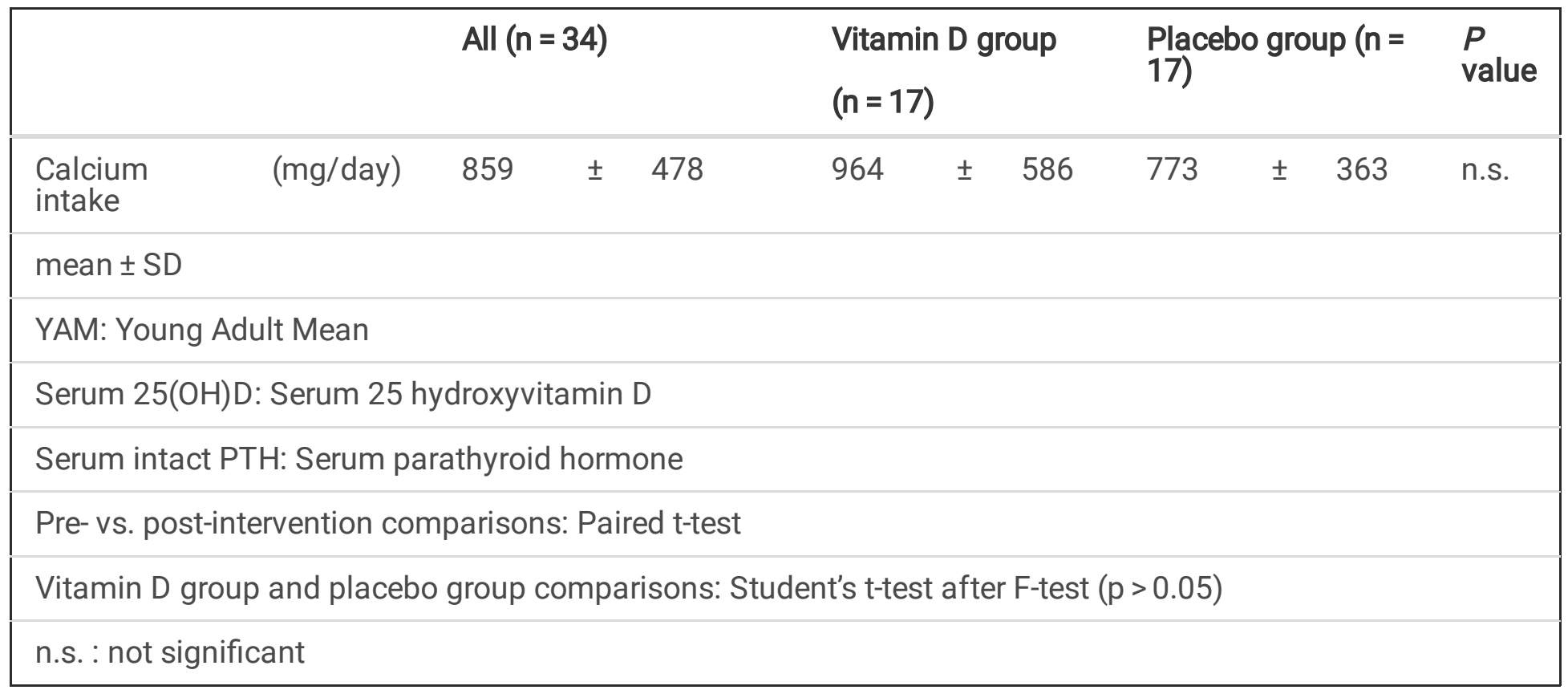

The results of the chi-squared test showed that there were no significant differences between the two groups in terms of the percentages of vitamin $D$ sufficiency and insufficiency $(p=0.14)$. The percentages of vitamin $D$ sufficiency were $47 \%$ in the vitamin D group and $53 \%$ in the placebo group.

\section{Mean energy intake amount and nutritional intake amount during the intervention period}

During the intervention period, the mean vitamin $D$ intake amount in the vitamin $D$ group was $40.0 \pm 5.5 \mu \mathrm{g} /$ day, of which $15.0 \pm 5.5 \mu \mathrm{g} /$ day was derived from the diet, whereas the mean vitamin $D$ intake amount in the placebo group was $13.4 \pm 7.7 \mu \mathrm{g} /$ day. No significant difference was found in the mean vitamin $D$ intake amounts between the two groups (Table 2). There were also no significant intergroup differences in the mean energy, protein, fat, carbohydrate, and calcium intake amounts. 
Table 2

Mean energy intake and nutrient intake amounts during the intervention period

\begin{tabular}{|c|c|c|c|c|c|c|c|c|}
\hline \multirow[b]{2}{*}{ Energy } & \multirow[b]{2}{*}{ (kcal/day) } & \multicolumn{3}{|c|}{$\begin{array}{l}\text { Vitamin } D \text { group }(n= \\
17)\end{array}$} & \multicolumn{3}{|c|}{$\begin{array}{l}\text { Placebo group }(n= \\
17)\end{array}$} & \multirow{2}{*}{$\begin{array}{l}P \text { value } \\
\text { n.s. }\end{array}$} \\
\hline & & 3,076 & \pm & 342 & 2,987 & \pm & 228 & \\
\hline Protein & (g/day) & 121.1 & \pm & 13.9 & 115.3 & \pm & 11.7 & n.s. \\
\hline Fat & (g/day) & 91.9 & \pm & 11.6 & 89.4 & \pm & 9.4 & n.s. \\
\hline Carbohydrates & (g/day) & 427.0 & \pm & 47.7 & 419.9 & \pm & 32.2 & n.s. \\
\hline Vitamin D (meals only) & ( $\mu \mathrm{g} /$ day) & 15.0 & \pm & 5.5 & 13.4 & \pm & 7.7 & n.s. \\
\hline \multicolumn{9}{|l|}{$\begin{array}{l}\text { (meals』vitamin } D_{3} \\
\text { supplement) }\end{array}$} \\
\hline Calcium & (mg/day) & 1,035 & \pm & 284 & 898 & \pm & 142 & n.s. \\
\hline \multicolumn{9}{|l|}{ mean $\pm S D$} \\
\hline \multicolumn{9}{|c|}{ Vitamin D group and placebo group comparisons: Student's t-test after F-test $(p>0.05)$} \\
\hline n.s., not significant & & & & & & & & \\
\hline
\end{tabular}

Relationship between post-intervention serum $25(\mathrm{OH}) \mathrm{D}$ concentration and the mean energy and nutrient intake amounts during the intervention period

The simple regression analysis' results showed that the post-intervention serum $25(\mathrm{OH}) \mathrm{D}$ concentration exhibited a significant correlation with the mean intake amounts of vitamin $D(r=0.54, p=0.001)$ and calcium ( $r$ $=0.34, p<0.05)$.

Furthermore, the multiple regression analysis demonstrated that both the mean vitamin $D$ intake amount $(p<$ $0.001)$ and pre-intervention serum $25(\mathrm{OH}) \mathrm{D}$ concentration $(\mathrm{p}<0.001)$ significantly contributed to the postintervention serum $25(\mathrm{OH})$ D concentration (Table 3). 
Table 3

Factors that contribute to the post-intervention serum $25(\mathrm{OH})$ D concentration

\begin{tabular}{|c|c|c|c|c|c|c|c|}
\hline & \multirow{2}{*}{$\begin{array}{l}\text { Partial } \\
\text { regression } \\
\text { coefficient }\end{array}$} & \multirow{2}{*}{$\begin{array}{l}\text { Standard } \\
\text { partial } \\
\text { regression } \\
\text { coefficient }\end{array}$} & \multirow{2}{*}{$\begin{array}{l}\text { Standard } \\
\text { coefficient } \\
\beta\end{array}$} & \multirow{2}{*}{$\begin{array}{l}P \\
\text { value }\end{array}$} & \multicolumn{2}{|l|}{$95 \% \mathrm{Cl}$} \\
\hline & & & & & & MIN & MAX \\
\hline Constant & & 5.919 & 2.653 & & 0.03 & 0.501 & 11.337 \\
\hline $\begin{array}{l}\text { Mean vitamin D } \\
\text { intake amount }\end{array}$ & ( $\mu \mathrm{g} /$ day) & 0.146 & 0.037 & 0.332 & $\hat{0}_{0.001}$ & 0.071 & 0.221 \\
\hline $\begin{array}{l}\text { Pre-intervention } \\
\text { serum } 25(\mathrm{OH}) \mathrm{D} \\
\text { concentration }\end{array}$ & $(\mathrm{ng} / \mathrm{mL})$ & 0.989 & .097 & 0.857 & $\begin{array}{l}< \\
0.001\end{array}$ & 0.790 & 1.187 \\
\hline \multicolumn{8}{|l|}{$\mathrm{n}=34$} \\
\hline \multicolumn{8}{|c|}{$R^{2}=0.844 \rrbracket \mathrm{ANOVA} \rrbracket 0.001$} \\
\hline \multicolumn{8}{|c|}{$\begin{array}{l}\text { Multiple regression (stepwise) analysis was performed with the post-intervention } 25(\mathrm{OH}) \mathrm{D} \text { concentration as } \\
\text { the dependent variable and the pre-intervention serum } 25(\mathrm{OH}) \mathrm{D} \text { concentration, mean vitamin } \mathrm{D} \text { intake } \\
\text { amount and mean calcium intake amount as the independent variables. }\end{array}$} \\
\hline \multicolumn{8}{|c|}{ Serum 25(OH)D: Serum 25 hydroxyvitamin D } \\
\hline
\end{tabular}

\section{Changes in pre-vs. post-intervention in the vitamin $D$ group and the placebo group}

There was a significant decrease in body fat percentage in both groups; the value in the vitamin $D$ group decreased from $11.2 \pm 1.5 \%$ to $10.5 \pm 1.6 \%$ and that in the placebo group decreased from $11.9 \pm 2.6 \%$ to $10.5 \pm$ $2.5 \%$ ( $<<0.01$ and $p<0.001$, respectively). In contrast, the mineral contents showed a significant increase in both groups; the value in the vitamin D group increased from $2840 \pm 347 \mathrm{~g}$ to $2891 \pm 338 \mathrm{~g}$ and that in the placebo group increased from $2935 \pm 240 \mathrm{~g}$ to $3000 \pm 222 \mathrm{~g}(\mathrm{p}<0.05$ and $\mathrm{p}<0.01$, respectively). The serum $25(\mathrm{OH}) \mathrm{D}$ concentration showed a significant increase in both groups, with the value in the vitamin $\mathrm{D}$ group increasing from $30.7 \pm 6.7 \mathrm{ng} / \mathrm{mL}$ to $35.4 \pm 6.6 \mathrm{ng} / \mathrm{mL}$ and that in the placebo group increasing from $27.1 \pm 3.9 \mathrm{ng} / \mathrm{mL}$ to $28.5 \pm 4.4 \mathrm{ng} / \mathrm{mL}(\mathrm{p}<0.001$ and $\mathrm{p}<0.01$, respectively). In the vitamin $\mathrm{D}$ group, the amount of increase in serum $25(\mathrm{OH}) \mathrm{D}$ per $1 \mu \mathrm{g}$ vitamin $\mathrm{D}_{3}$ was $0.19 \pm 0.15 \mu \mathrm{g}$. The serum Ca concentration showed a significant decline only in the placebo group, from $9.6 \pm 0.2 \mathrm{mg} / \mathrm{dL}$ to $9.3 \pm 0.2 \mathrm{mg} / \mathrm{dL}(\mathrm{p}<0.001)$, whereas the serum IL-6 concentrations showed a significant decline in the vitamin $D$ group only, from $0.68 \pm 0.29 \mathrm{pg} / \mathrm{mL}(\mathrm{p}<0.01)$. Weight, serum intact PTH concentration, and serum P concentration exhibited no pre- vs. post-intervention intergroup differences.

The analysis of variance results showed that the serum $25(\mathrm{OH}) \mathrm{D}$ and serum Ca concentrations were significantly higher $(p<0.001$ and $p<0.05$, respectively, ) and the serum intact PTH concentration was significantly lower $(p<0.05$, Fig. 1$)$ in the vitamin $D$ group than in the placebo group. The percentage of sufficient vitamin D was $82 \%$ in the vitamin D group and $43 \%$ in the placebo group, showing a significant intergroup difference $(p<0.01)$.

\section{Relationship between the rate of pre-vs. post-intervention change in serum $25(\mathrm{OH}) \mathrm{D}$ concentration}

The rate of change in the pre- vs. post-intervention serum $25(\mathrm{OH}) \mathrm{D}$ concentrations was found to be positively correlated to the mean vitamin $D$ intake amounts $(r=0.423, p<0.05$; Fig. 2). No significant relation was found 
with mean energy and other nutrients' intake amounts. Furthermore, investigation of the rate of change between the pre-vs. post-intervention serum $25(\mathrm{OH}) \mathrm{D}$ concentrations in the vitamin $\mathrm{D}$ group exhibited a negative correlation with the pre-intervention serum $25(\mathrm{OH})$ D concentration $(r=-0.485, p<0.05$; Fig. 3$)$.

\section{Discussion}

In this study, we investigated changes in the winter-time serum $25(\mathrm{OH})$ D concentrations of university longdistance runners following vitamin $D_{3}$ supplementation. The subjects were athletes who engaged in training mainly in long-distance running outdoors six days per week.

Long-distance running places a repeated weight load on the bones, and it is associated with a high prevalence of fatigue fracture caused by local decreases in bone mass, resulting from the bone's inability to sufficiently repair itself [24]. Previous studies have reported on the control of decreases in bone mass and density, which are associated with long-distance running, high bone turnover, and inhibited bone formation owing to increased PTH [25-27]. This indicates that a nutritional approach designed to ensure preventative bone health is required. Warden et al. [28] reported that calcium and vitamin $D$ are required to prevent stress fractures in long-distance runners, and a study by Lappe et al. [15] that focused on new military recruits found that calcium and vitamin $D$ supplements had a suppressive effect on fatigue fracture onset. Of these two nutrients, vitamin D insufficiency and deficiency are particularly problematic in Japan.

The bone density of the subjects in the present study was $100 \%$ below YAM, which--as Fredericson et al. [29] reported--indicates low bone density. This result is indicative of athletes involved in long-distance running. The pre-intervention vitamin $D$ intake amount was $16.7 \pm 7.2 \mu \mathrm{g} /$ day, which exceeded the target amount, but the vitamin D nutritional status index--serum $25(\mathrm{OH})$ D concentration-- was $28.9 \pm 5.7 \mathrm{ng} / \mathrm{mL}$, and the high percentage of subjects with vitamin D insufficiency (65\%) suggests that the target amount currently in use is insufficient. Serum $25(\mathrm{OH}) \mathrm{D}$ concentration is affected by ultraviolet light irradiation; it displays seasonal variations, with lower levels during the winter than in summer $[10,11]$. This suggests a need to review vitamin $D$ intake amounts in individuals who engage in outdoor activities to ensure that they obtain sufficient amounts of vitamin D.

Holick et al. [30] reported that individuals with vitamin D insufficiency or deficiency require 37.5-50 $\mu \mathrm{g}$ of vitamin D supplementation to maintain a serum $25(\mathrm{OH}) \mathrm{D}$ concentration of at least $30 \mathrm{ng} / \mathrm{mL}$. In their vitamin $D$ interventional study of underwater patrol staff (divers) receiving limited amounts of ultraviolet light, Gasier et al. [31] reported that their serum $25(\mathrm{OH}) \mathrm{D}$ concentration improved following supplementation with $50 \mu \mathrm{g} / \mathrm{day}$ of vitamin D over a 12-week period, and significant effectiveness was not obtained through the use of $<50 \mu \mathrm{g} / \mathrm{day}$. In the present study, the subjects in the vitamin D group obtained an average of $40 \mu \mathrm{g} /$ day of vitamin $D$ during the intervention period from their normal diet and $25 \mu \mathrm{g} /$ day of vitamin D supplement, and the percentage of vitamin D sufficiency in that group increased considerably from $47-82 \%$. In contrast, investigation of the mean vitamin $D$ intake during the intervention period in the placebo group showed that the percentage of vitamin $D$ sufficiency declined from 53-43\% over the course of the study. Our post-intervention comparison of the two groups showed that the vitamin D group had a lower serum intact PTH concentration and a higher serum Ca concentration than the placebo group. Comparison of the vitamin $D$ and placebo groups also suggested that although vitamin D supplementation resulted in improved vitamin D nutritional status in the vitamin D group, 
improvement in the vitamin D nutritional status in the placebo group did not lead to sufficient improvement in vitamin $D$ nutritional status.

There was no significant difference in the mineral contents between the two groups; however, the concentration of serum IL-6 showed a significant decline in the vitamin D group only. Vitamin D is also known to play a role in the regulation of inflammatory cytokines, such as down-regulating the expression of TNF-alpha and IL-6 in the general population [32]. Although few studies have described this relationship in athletes, training load can increase inflammatory cytokines (TNF-alpha and IL-6) and inhibit bone formation. Thus, further investigation is needed regarding the effects of sufficient vitamin $D$ supplementation on reduced risk of disability.

Vitamin D and calcium supplements resulted in an increased serum calcium concentration and control of PTH activation, which supports bone health [33]. Calcium and vitamin D intake is effective in the prevention of fatigue fracture in athletes [15]. In their randomized controlled trial, Gaffney-Stomberg et al. [34] also found that these supplements contributed to the improvement in bone status under conditions wherein the risk of fatigue fracture is elevated owing to increased serum PTH levels during training with repeated mechanical loads. In the current study, the mean calcium intake amounts in both groups during the intervention period exceeded the recommended amount. Thus, the significant difference between the groups at the post-intervention time point was likely owing to the effects of the amounts of vitamin D intake.

Vitamin D supplementation is believed to be effective on serum $25(\mathrm{OH}) \mathrm{D}$ concentration during the winter months, when the baseline serum $25(\mathrm{OH}) \mathrm{D}$ level is low and ultraviolet light is less plentiful [35]. In the present study, the mean vitamin $D$ intake amount was positively correlated to the amount of change in the serum 25 $(\mathrm{OH}) \mathrm{D}$ concentration, and it was dose responsive. In addition, in the vitamin D group, the pre-intervention serum $25(\mathrm{OH}) \mathrm{D}$ concentration was found to be negatively correlated to the rate of change in the serum $25(\mathrm{OH}) \mathrm{D}$ concentration. Multiple regression analysis showed that the post-intervention serum $25(\mathrm{OH}) \mathrm{D}$ concentration was related to the mean vitamin $D$ intake amount during the intervention period and the pre-intervention serum $25(\mathrm{OH}) \mathrm{D}$ concentration. These results suggest that the effectiveness of vitamin $\mathrm{D}$ supplementation using preintervention serum $25(\mathrm{OH}) \mathrm{D}$ concentrations also needs to be investigated in the subjects of this study.

In the vitamin D group, the amount of increase in serum $25(\mathrm{OH}) \mathrm{D}$ concentration per $1 \mu \mathrm{g}$ of vitamin $\mathrm{D}_{3}$ was less than has been reported previously [36]. This is likely owing to the fact that the subjects of the present study underwent nutritional education regarding vitamin $\mathrm{D}$ intake for the purpose of maintaining daily bone health and were provided a diet fortified with vitamin D, which implies that their pre-intervention serum $25(\mathrm{OH}) \mathrm{D}$ concentration was higher than that of previous studies.

We did not assess bone status or the risk of fatigue fracture resulting from vitamin $D_{3}$ intervention, which was one of the limitations of the present study. Although we measured BMC and bone density prior to intervention, because the intervention period was short, at only 31 days, it was impossible to measure post-intervention values; therefore, we were unable to investigate their relation with vitamin D supplement intake. Thus, to identify the required amount of vitamin $D$ intake in individuals with a high rate of fatigue fracture, such as the longdistance runners in the present study, further study of the effectiveness of vitamin $D$ supplementation on bone health is required.

Another limitation of this study was the fact that we were unable to identify the effect of the subjects' low body fat percentage on serum $25(\mathrm{OH})$ D concentration. Because serum $25(\mathrm{OH}) \mathrm{D}$ concentration is negatively 
correlated to body fat amount [37], it is likely that the low body fat percentage of the subjects in this study increased the response to the blood concentration based on the amount of vitamin $D$ intake. Therefore, there is a need to investigate the body compositions of athletes engaged in different sports to verify that changes in serum $25(\mathrm{OH})$ D concentration were the result of vitamin D supplement intake.

\section{Conclusions}

Male university long-distance runners who suffered from vitamin D insufficiency showed a significant increase in serum $25(\mathrm{OH})$ D concentration and improvement in their vitamin D nutritional status after receiving $25 \mu \mathrm{g} / \mathrm{day}$ vitamin $\mathrm{D}_{3}$ supplement for a 31-day period during winter. Our results demonstrate that post-intervention serum $25(\mathrm{OH}) \mathrm{D}$ concentration was related to both mean vitamin $\mathrm{D}$ intake amount during the intervention period and pre-intervention serum $25(\mathrm{OH}) \mathrm{D}$ concentration. However, to better quantify the required amount of vitamin $\mathrm{D}$, further study of the effect of vitamin D supplementation on bone health is needed.

\section{Abbreviations}

25 (OH) D 25 hydroxyvitamin D

DBP Vitamin D binding protein

Ca Calcium

BMC Bone mineral content

BMD Bone mineral density

BMI Body Mass Index

YAM Young adult mean

P Phosphorus

PTH Parathyroid hormone

IL-6 Interleukin-6

\section{Declarations}

\section{Ethics approval and consent to participate}

This study was approved by the Institutional Review Board of Teikyo University (no. 18-155), and all subjects provided informed written consent.

\section{Consent for publication}

All participants provided written informed consent for publication of the study.

\section{Availability of data and materials}


The datasets used and/or analysed during the current study are available from the corresponding author on reasonable request.

\section{Competing interests}

The authors declare that they have no competing interests.

\section{Funding}

This study was supported by Teikyo University Institute of Sports Science \& Medicine, Tokyo, Japan.

\section{Author contributions}

MT, and MK collected the data. MT, MK conceived the study and analyzed the results. TN, and JS supervised the study and prepared the manuscript. All authors read and approved the final manuscript.

\section{Acknowledgements}

The authors would like to express their appreciation to the subjects, managers, and coaches who participated in this study.

\section{References}

1. Prietl B, Treiber G, Pieber TR, Amrein K. Vitamin D and immune function. Nutrients. 2013;5:2502-21.

2. Walrand S. Effect of vitamin D on skeletal muscle. Geriatr Psychol Neuropsychiatr Vieil. 2016;14:127-34.

3. Brustad M, Alsaker E, Engelsen O, Aksnes L, Lund E. Vitamin D status of middle-aged women at $65-71^{\circ} \mathrm{N}$ in relation to dietary intake and exposure to ultraviolet radiation. Public Health Nutr. 2004;7:327-35.

4. Okazaki R, Sugimoto T, Kaji H, Fujii Y, Shiraki M, Inoue D, et al. Vitamin D insufficiency defined by serum 25hydroxyvitamin D and parathyroid hormone before and after oral vitamin D-load in Japanese subjects. J Bone Miner Metab. 2011;29:103-10.

5. Tanaka S, Kuroda T, Yamazaki Y, Shiraki Y, Yoshimura N, Shiraki M. Serum 25-hydroxyvitamin D below 25 $\mathrm{ng} / \mathrm{mL}$ is a risk factor for long bone fracture comparable to bone mineral density in Japanese postmenopausal women. J Bone Miner Metab. 2014;32:514-23.

6. Bischoff-Ferrari HA, Borchers M, Gudat F, Dürmüller U, Stähelin HB, Dick W. Vitamin D receptor expression in human muscle tissue decreases with age. J Bone Miner Res. 2004;19:265-9.

7. Holick MF, Chen TC. Vitamin D deficiency: a worldwide problem with health consequences. Am J Clin Nutr. 2008;87:1080S-6S.

8. Mehran N, Schulz BM, Neri BR, Robertson WJ, Limpisvasti O. Prevalence of vitamin D insufficiency in professional hockey players. Orthop J Sports Med. 2016;4:1-4.

9. Maroon JC, Mathyssek CM, Bost JW, Amos A, Winkelman R, Yates AP, et al. Vitamin D profile in National Football League players. Am J Sports Med. 2015;43:1241-5.

10. Morton JP, lqbal Z, Drust B, Burgess D, Close GL, Brukner PD. Seasonal variation in vitamin D status in professional soccer players of the English Premier League. Appl Physiol Nutr Metab. 2012;37:798-802. 
11. Maruyama-Nagao A, Sakuraba K, Suzuki Y. Seasonal variations in vitamin D status in indoor and outdoor female athletes. Biomed Rep. 2016;5:113-7.

12. Ruohola JP, Laaksi I, Ylikomi T, Haataja R, Mattila VM, Sahi T, et al. Association between serum 25(OH)D concentrations and bone stress fractures in Finnish young men. J Bone Miner Res. 2006;21:1483-8.

13. Davey T, Lanham-New SA, Shaw AM, Hale B, Cobley R, Berry JL, et al. Low serum 25-hydroxyvitamin D is associated with increased risk of stress fracture during Royal Marine recruit training. Osteoporos Int. 2016;27:171-9.

14. Burgi AA, Gorham ED, Garland CF, Mohr SB, Garland FC, Zeng K, et al. High serum 25-hydroxyvitamin D is associated with a low incidence of stress fractures. J Bone Miner Res. 2001;26:2371-7.

15. Lappe J, Cullen D, Haynatzki G, Recker R, Ahlf R, Thompson K. Calcium and vitamin d supplementation decreases incidence of stress fractures in female navy recruits. J Bone Miner Res. 2008;23:741-9.

16. Larson-Meyer DE, Willis KS. Vitamin D and athletes. Curr Sports Med Rep. 2010;9:220-6.

17. Owens DJ, Allison R, Close GL. Vitamin D and the athlete: current perspectives and new challenges. Sports Med. 2018;48:3-16.

18. Han Q, Li X, Tan Q, Shao J, Yi M. Effects of vitamin D3 supplementation on serum 25(OH)D concentration and strength in athletes: a systematic review and meta-analysis of randomized controlled trials. J Int Soc Sports Nutr. 2019;16:55.

19. Jung HC, Seo MW, Lee S, Kim SW, Song JK. Vitamin D3 supplementation reduces the symptoms of upper respiratory tract infection during winter training in vitamin D-insufficient taekwondo athletes: a randomized controlled trial. Int J Environ Res Public Health. 2018;15:2003.

20. Marley A, Grant MC, Babraj J. Weekly vitamin D(3) supplementation improves aerobic performance in combat sport athletes. Eur J Sport Sci. 2020; March 31:1- doi:10.1080/17461391.2020.1744736.

21. Food and Nutrition Board, Institute of Medicine. Dietary reference intakes for calcium and vitamin D. National Academy Press: Washington DC; 2011.

22. Dai-Ichi Shuppan Group (eds.). Dietary Reference Intakes for Japanese. 2020 ed. Shuppan, Tokyo: Dai-Ichi; 2020.

23. Okazaki R, Ozono K, Fukumoto S, Inoue D, Yamauchi M, Minagawa M, et al. Assessment criteria for vitamin D deficiency/insufficiency in Japan: proposal by an expert panel supported by the Research Program of Intractable Diseases, Ministry of Health, Labour and Welfare, Japan, the Japanese Society for Bone and Mineral Research and the Japan Endocrine Society [Opinion]. J Bone Miner Metab. 2017;35:1-5.

24. Harrast MA, Colonno D. Stress fractures in runners. Clin Sports Med. 2010;29:399-416.

25. Hetland ML, Haarbo J, Christiansen C. Low bone mass and high bone turnover in male long distance runners. J Clin Endocrino Metab. 1993;77:770-5.

26. Kemmler W, Engelke K, Baumann H, Beeskow C, von Stengel S, Weineck J, et al. Bone status in elite male runners. Eur J Appl Physiol. 2006;96:78-85.

27. Mouzopoulos G, Stamatakos M, Tzurbakis M, Tsembeli A, Manti C, Safioleas M, et al. Changes of bone turnover markers after marathon running over 245 km. Int J Sports Med. 2007;28:576-9.

28. Warden SJ, Davis IS, Fredericson M. Management and prevention of bone stress injuries in long-distance runners. J Orthop Sports Phys Ther. 2014;44:749-65. 
29. Fredericson M, Chew K, Ngo J, Cleek T, Kiratli J, Cobb K. Regional bone mineral density in male athletes: a comparison of soccer players, runners and controls. Br J Sports Med. 2007;41:664-8.

30. Holick MF, Binkley NC, Bischoff-Ferrari HA, Gordon CM, Hanley DA, Heaney RP, et al. Evaluation, treatment, and prevention of vitamin D deficiency: an Endocrine Society clinical practice guideline. J Clin Endocrinol Metab. 2011;96:1911-30.

31. Gasier HG, Gaffney-Stomberg E, Young CR, McAdams DC, Lutz LJ, McClung JP. The efficacy of vitamin D supplementation during a prolonged submarine patrol. Calcif Tissue Int. 2014;95:229-39.

32. Calton EK, Keane KN, Newsholme P, Soares MJ. The impact of vitamin D levels on inflammatory status: a systematic review of immune cell studies. PLoS One. 2015;10:e0141770.

33. Hill TR, Aspray TJ, Francis RM. Vitamin D and bone health outcomes in older age. Proc Nutr Soc. 2013;72:372-80.

34. Gaffney-Stomberg E, Lutz LJ, Rood JC, Cable SJ, Pasiakos SM, Young AJ, et al. Calcium and vitamin D supplementation maintains parathyroid hormone and improves bone density during initial military training: a randomized, double-blind, placebo controlled trial. Bone. 2014;68:46-56.

35. Webb AR, Kline L, Holick MF. Influence of season and latitude on the cutaneous synthesis of vitamin D3: exposure to winter sunlight in Boston and Edmonton will not promote vitamin D3 synthesis in human skin. J Clin Endocrinol Metab. 1998;67:373-8.

36. Heaney RP, Davies KM, Chen TC, Holick MF, Barger-Lux MJ. Human serum 25-hydroxycholecalciferol response to extended oral dosing with cholecalciferol. Am J Clin Nutr. 2003;77:204-10.

37. Golzarand M, Hollis BW, Mirmiran P, Wagner CL, Shab-Bidar S. Vitamin D supplementation and body fat mass: a systematic review and meta-analysis. Eur J Clin Nutr. 2018;72:1345-57.

\section{Figures}

a

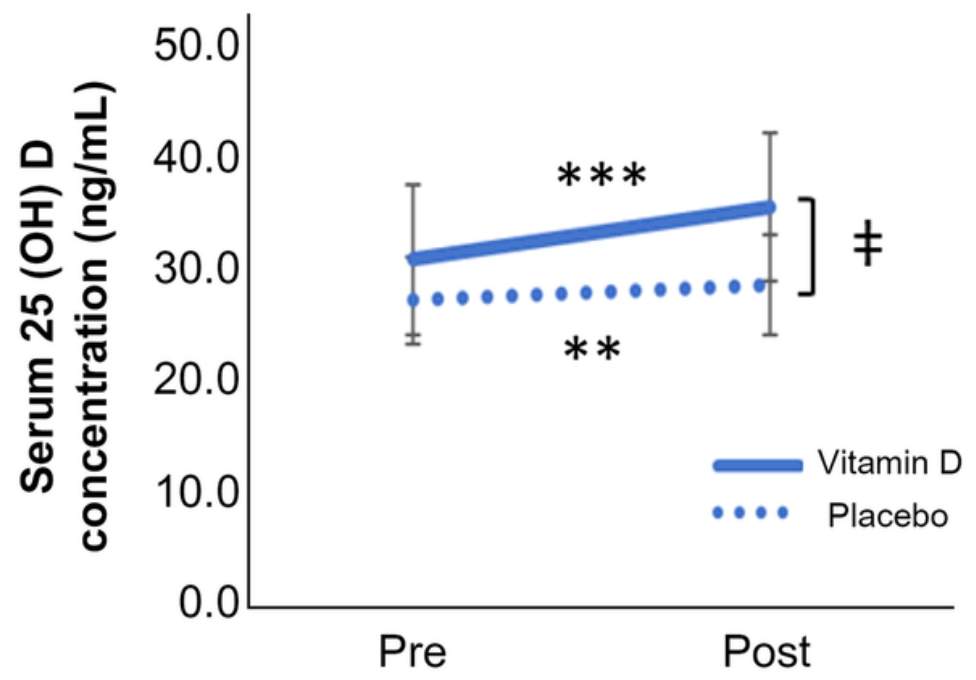

b

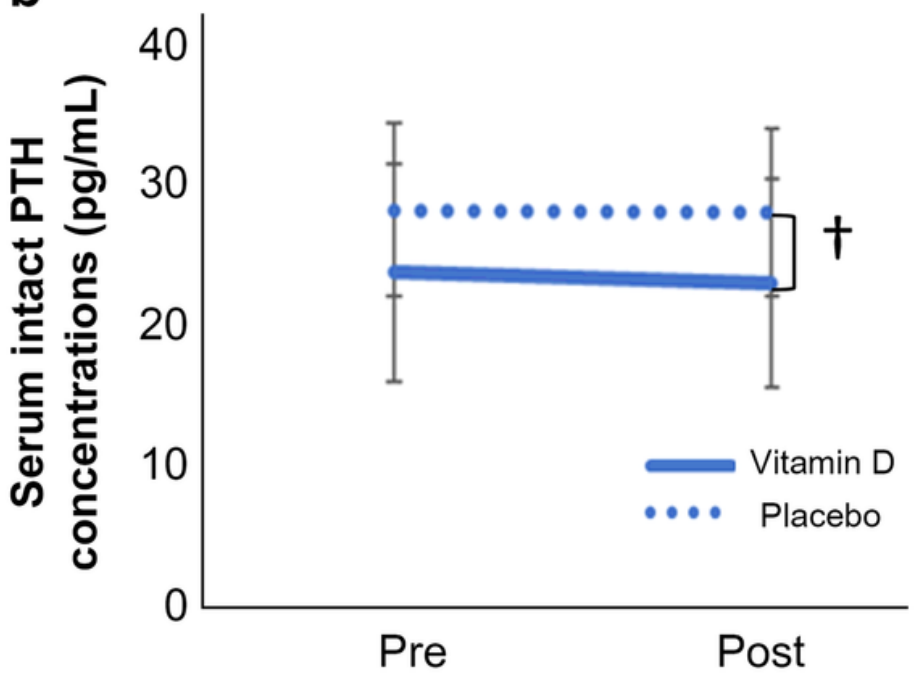

Figure 1

Changes in serum $25(\mathrm{OH}) \mathrm{D}$ and serum intact PTH concentrations a indicates the pre- vs. post-intervention serum $25(\mathrm{OH})$ D concentration, and b indicates the pre- vs. post-intervention serum intact PTH concentration. 
Comparison of the post-intervention serum $25(\mathrm{OH}) \mathrm{D}$ and serum intact PTH concentrations in the vitamin D and placebo groups to the pre-intervention values was performed using analysis of variance with covariates. $\dagger: p<$ $0.05, \ddagger: p<0.001$. Comparisons of pre- vs. post-intervention values in both groups were performed using the paired t-test. **: $p<0.01, * \star *: p<0.001$

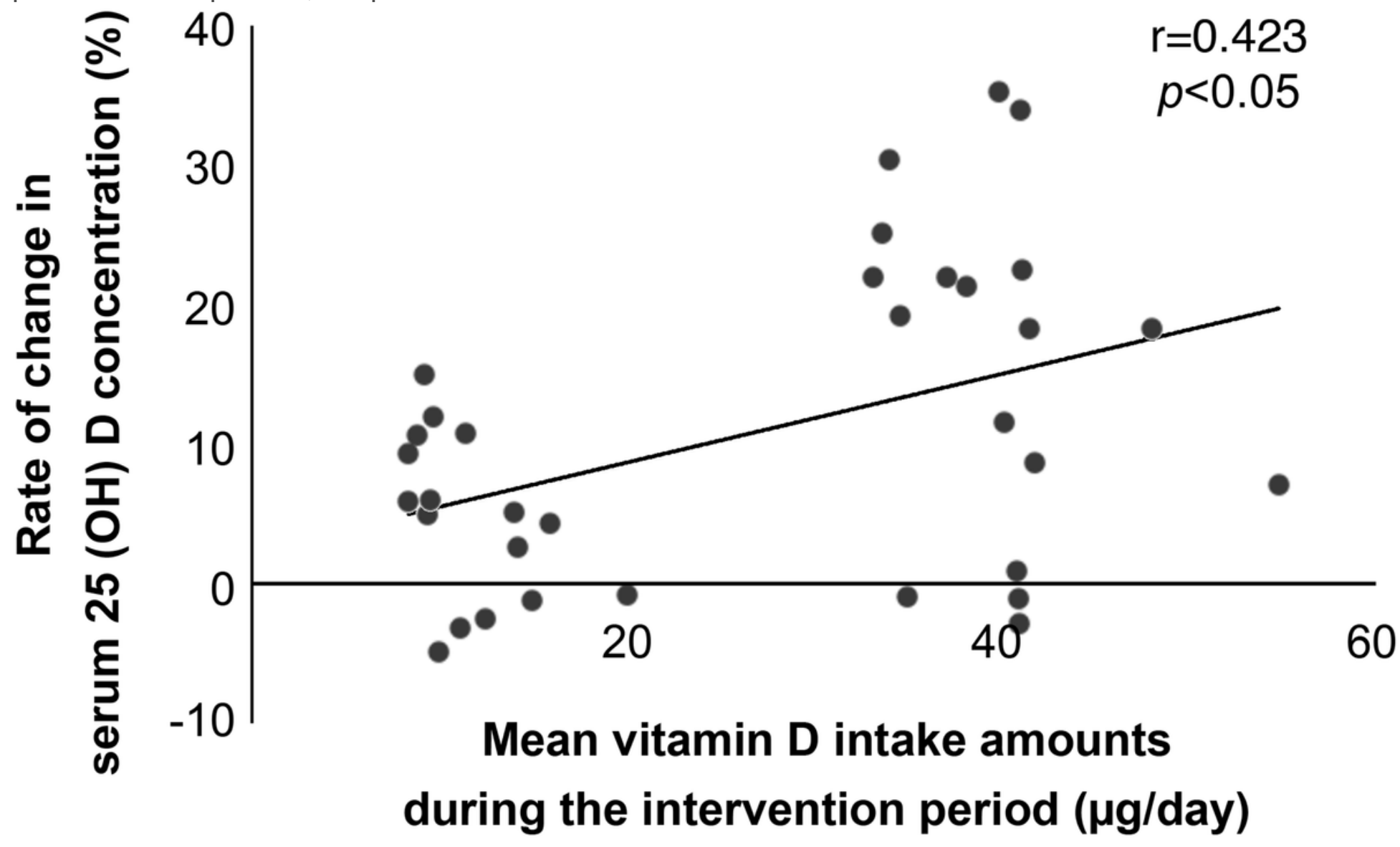

Figure 2

Relationship between serum $25(\mathrm{OH}) \mathrm{D}$ concentration changes and vitamin D intake amounts Analysis performed using Pearson's product moment correlation coefficient. 


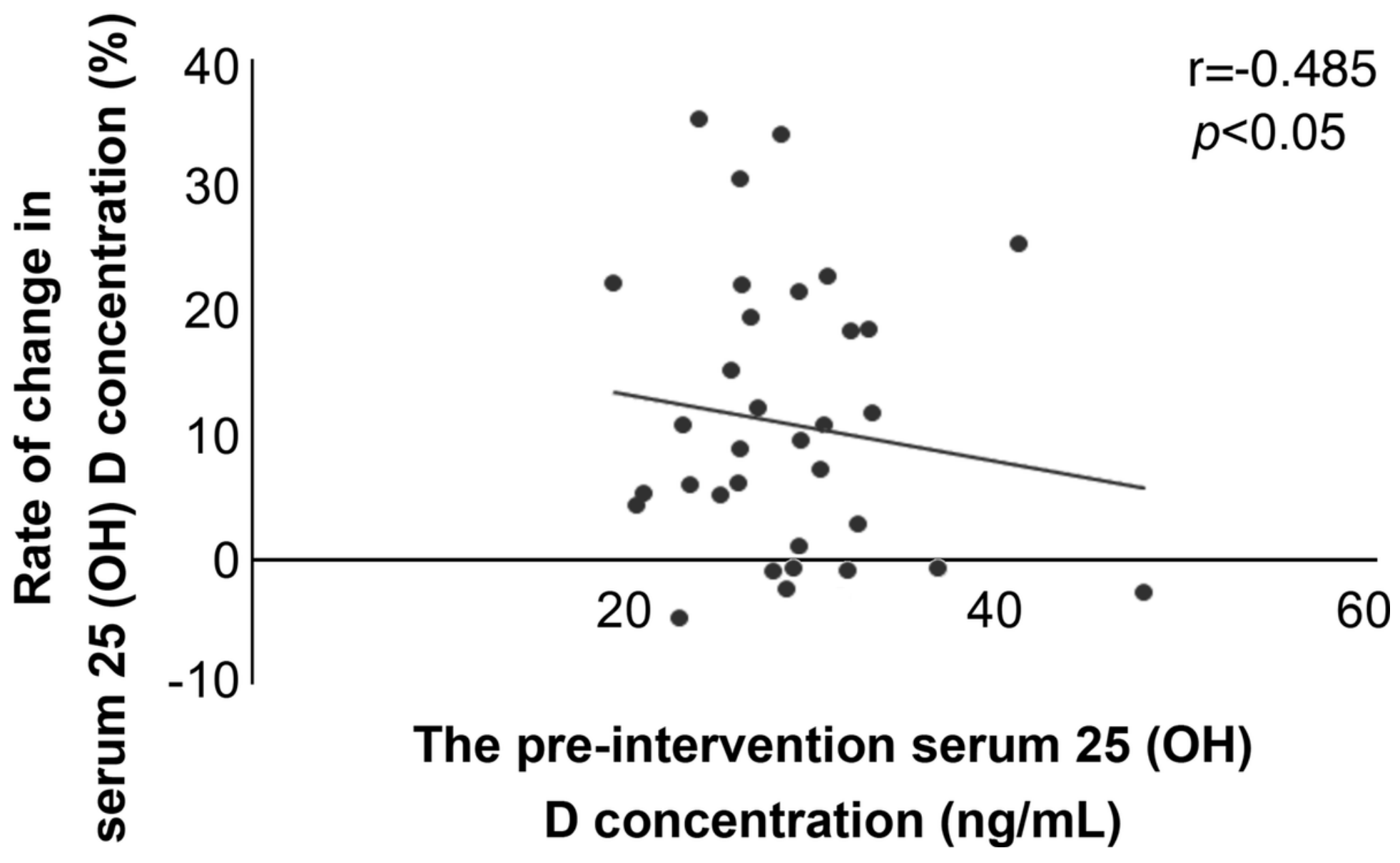

Figure 3

Relationship between the change in and pre-intervention levels of serum $25(\mathrm{OH}) \mathrm{D}$ concentration Analysis performed using Pearson's product moment correlation coefficient. 